\title{
Obituaries
}

\section{DENIS REGAN}

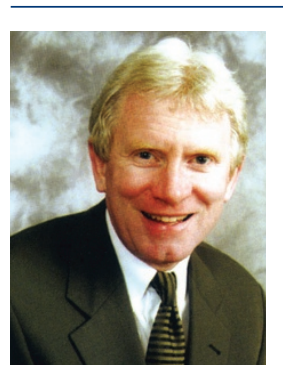

Denis Regan was an exceptional clinician and teacher who died on 30 May 2009 after a long illness.

Denis taught orthodontics to Sheffield's dental students for over ten years. He was a champion of clinical excellence and a consummate teacher. Those who had the good fortune to work with him will always remember his wonderful personality, freshness and sense of humour.

Denis was born in 1946 and studied dentistry at the University of Manchester, qualifying in 1968. He worked as a general dental practitioner in Lancashire from 1969-1979 and in Matlock from 1980-1983. He started his early teaching career teaching dental surgery assistants at Stretford Technical College. In 1981 he was appointed Clinical Assistant at the Charles Clifford Dental Hospital in Sheffield. He obtained his MSc in 1983 and was subsequently appointed as Lecturer in Child Dental Health at the University of Sheffield in late 1983. He obtained his Diploma in Orthodontics from The Royal College of Surgeons of England in 1987.

For over ten years as Lecturer in Orthodontics in Sheffield, he taught over 500 dental students and supervised many postgraduates and their Masters dissertations. In 1994 he became a part-time lecturer and entered Specialist Orthodontic Practice in Mansfield. Denis was a highly successful specialist and was well loved by both his patients and his referring dentists. He continued teaching in Sheffield, delivering a substantial part of the formal lecture course in orthodontics. Denis continued to develop his teaching and educational skills and gave courses throughout the UK, and subsequently throughout Europe.

All who worked with Denis fondly remember his great enthusiasm for life, for dentistry and for education, as well as all things associated with Manchester United. He was a season ticket holder for many years and would constantly remind his students where the pinnacle of football is played!

Denis will be missed by his students and clinical colleagues. He is survived by his wife, Jayne, and his four adult children. Denis was one of the great quiet men of orthodontics and the specialty is much poorer for his loss.

D. R. Willmot, P. E. Benson

\section{JOHN KEVIN ELTRINGHAM}

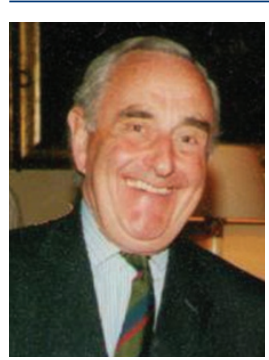

Kevin Eltringham (26 May 1934 - 13 August 2009) was a larger than life figure. Qualifying from Birmingham in 1958, he joined the Royal Army Dental Corps, where he was a notable success, both as a dentist and as an administrator. His appointment as the first ever dentist to be appointed Adjutant to the General of the Royal Army Medical Corps at Milbank initially ruffled some military medical feathers, but he was soon more than accepted, and he left the army with the rank of Lieutenant Colonel.

Posted to Singapore in 1970 he met his lifetime companion Dr Ong. It was at their house in Billingford, converted from an ox pen, with its extensive
Obituaries should be submitted by email to Kate Maynard at k.maynard@nature.com.

All submitted obituaries should be 350 words maximum in length (apart from obituaries for past presidents of the BDA

where the length should be 700-800 words)

Content of the obituary is down to the individual author, and the approval of the family should be given for the obituary prior

to submission to the $B D J$.

grounds and inventive water features laid out by Kevin, that he died suddenly from a heart attack.

The service at the parish Church of St. Peter was attended by representatives from all the walks of life that made for Kevin's obvious enjoyment of living, the dental world, for after leaving the army he had founded one of the most prestigious of private practices in London, treating the great and the good, the local community of Billingford where he had been a stalwart of the church and village life, his Masonic friends, and friends from the Athenaeum, both of which latter organisations had been so much enjoyed by him, and to which he had added his own sparkle.

His character was complex. The bon viveur, who so much enjoyed his food and wine, and whose most excellent home-made pickles were served at the funeral reception, should be contrasted with the man who quietly ran one of the first clinics for HIV positive patients, who were being denied private dental care because of their illness. Referrals came mainly from St. Mary's Paddington. He also provided free dental treatment to several in the congregation of his London church, St. Paul's Knightsbridge, who were unable to afford fees.

His friends value the memory of his good company, and his family remember the brother and favourite uncle. For Dr Ong, the loss is much the greatest.

MB KE 